Nevada

Environmental

Restoration

Project

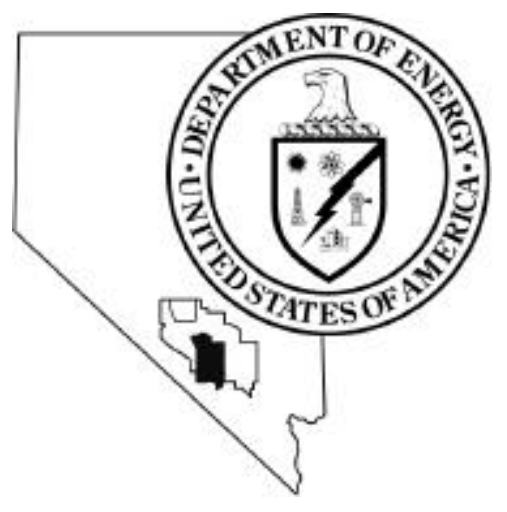

Addendum to the Corrective Action

Decision Docum ent for Corrective Action Unit 25 4: Area 25 R-M AD

Decontam ination Facility,

$\mathrm{N}$ evada Test Site, $\mathrm{N}$ evada

Controlled Copy N $0 .:$

Revision N 0.: 0

December 2000

Approved for public release; further dissemination unlimited.

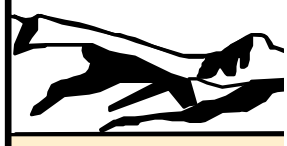

Environm ental Restoration

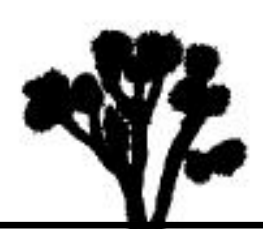

Division 
Available for public sale, in paper, from:

\author{
U.S. Department of Commerce \\ National Technology Information Service \\ 5285 Port Royal Road \\ Springfield, VA 22161 \\ Phone: 800.553 .6847 \\ Fax: 703.605.6900 \\ Email: orders@ntis.fedworld.gov \\ Online ordering: http//www.ntis.gov/ordering.htm
}

Available electronically at http://www.doe.gov/bridge.

Available for a processing fee to U.S. Department of Energy and its contractors, in paper, from:

\author{
U.S. Department of Energy \\ Office of Scientific and Technical Information \\ P.O. Box 62 \\ Oak Ridge, TN 37831-0062 \\ Phone: 865.576 .8401 \\ Fax: 865.576.5728 \\ Email: reports@adonis.osti.gov
}

Reference herein to any specific commercial product, process, or service by trade name, trademark, manufacturer, or otherwise, does not necessarily constitute or imply its endorsement, recommendation, or favoring by the United States Government or any agency thereof or its contractors or subcontractors. 


\title{
ADDENDUM TO THE CORRECTIVE ACTION DECISION DOCUMENT FOR CORRECTIVE ACTION UNIT 254: AREA 25 R-MAD DECONTAMINATION FACILITY, NEVADA TEST SITE, NEVADA
}

\author{
DOE Nevada Operations Office \\ Las Vegas, Nevada
}

Controlled Copy No.:

Revision No.: 0

December 2000

Approved for public release; further dissemination unlimited. 


\title{
ADDENDUM TO THE CORRECTIVE ACTION DECISION DOCUMENT FOR CORRECTIVE ACTION UNIT 254: \\ AREA 25 R-MAD DECONTAMINATION FACILITY NEVADA TEST SITE, NEVADA
}

\author{
Approved by:




\section{Table of Contents}

List of Figures . . . . . . . . . . . . . . . . . . . . . . . . .

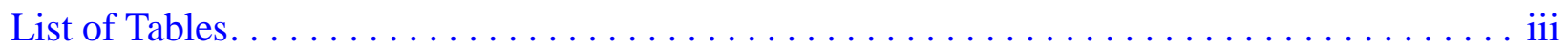

List of Acronyms and Abbreviations $\ldots \ldots \ldots \ldots \ldots \ldots \ldots \ldots \ldots \ldots \ldots \ldots \ldots \ldots \ldots$

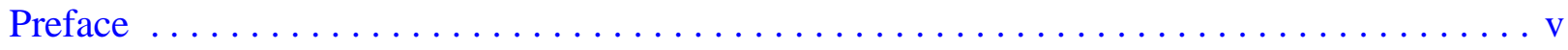

$1.0 \quad$ Introduction. . . . . . . . . . . . . . . . . . . . . . . . . .

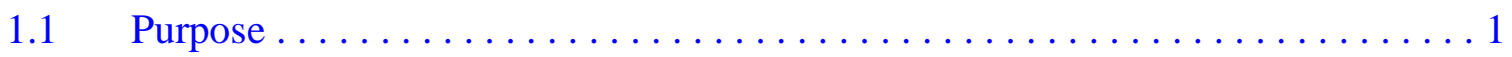

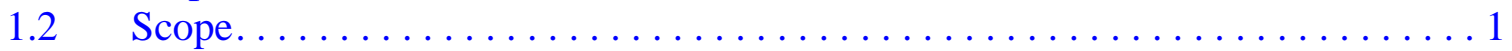

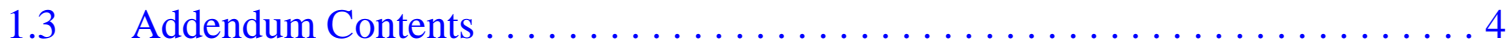

2.0 Corrective Action Investigation Summary $\ldots \ldots \ldots \ldots \ldots \ldots \ldots \ldots \ldots \ldots \ldots \ldots$

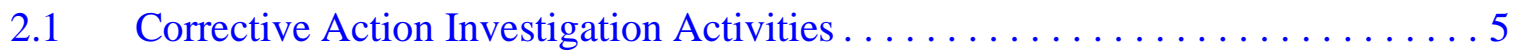

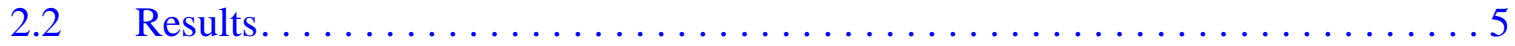

$2.3 \quad$ Need for Corrective Action. . . . . . . . . . . . . . . . . . . . . . 5

Evaluation of Corrective Action Alternatives $\ldots \ldots \ldots \ldots \ldots \ldots \ldots \ldots \ldots$

3.1 Corrective Action Objectives . . . . . . . . . . . . . . . . 6

3.1.1 Contaminants of Concern. . . . . . . . . . . . . . . . 6

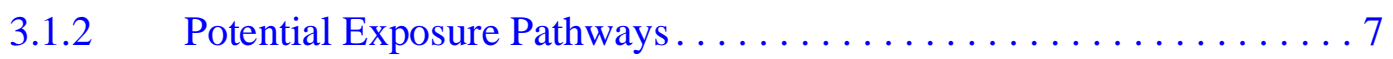

$3.2 \quad$ Screening Criteria . . . . . . . . . . . . . . . . . . . . . . 7

3.3 Development of Corrective Action Alternatives $\ldots \ldots \ldots \ldots \ldots \ldots \ldots \ldots 7$

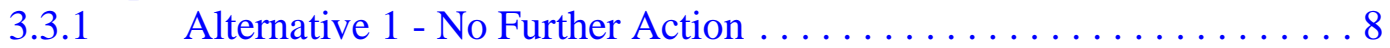

3.3.2 Alternative 2 - Unrestricted Release Decontamination and Verification Survey ................... 8

3.3.3 Alternative 3 - Unrestricted Release Decontamination, Verification Survey, and Dismantle of Building $3126 \ldots \ldots \ldots$

3.4 Evaluation and Comparison of Alternatives. . . . . . . . . . . . . 9

$4.0 \quad$ Recommended Corrective Action Alternative . . . . . . . . . . . . . . . . 16

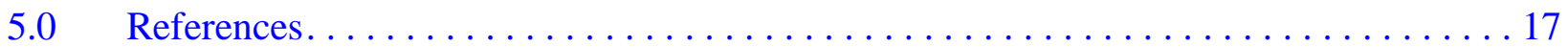

\section{Appendix A - Cost Estimates}




\section{List of Figures}

Number

1-1 Nevada Test Site and CAU 254, Area 25 R-MAD Decontamination Facility, Location Map . . . . . . . . . . . . . . . . . . . . . . . 2

1-2 CAU 254, Area 25 R-MAD Location Map . . . . . . . . . . . . . . . . . . . . . . 3 


\section{List of Tables}

Number

3-1 Detailed Evaluation of the Corrective Action Alternatives

for CAU 254, Area 25 R-MAD Decontamination Facility . . . . . . . . . . . . . . 11

3-2 Evaluation and Comparison of the Corrective Action Alternatives

for CAU 254, Area 25 R-MAD Decontamination Facility . . . . . . . . . . . . 15 


\section{List of Acronyms and Abbreviations}

\begin{tabular}{|c|c|}
\hline ALARA & As-low-as-reasonably-achievable \\
\hline CADD & Corrective Action Decision Document \\
\hline CAIP & Corrective Action Investigation Plan \\
\hline CAS & Corrective Action Site \\
\hline CAU & Corrective Action Unit \\
\hline CFR & Code of Federal Regulations \\
\hline $\mathrm{COC}$ & Contaminant(s) of concern \\
\hline $\mathrm{COPC}$ & Contaminant(s) of potential concern \\
\hline Cs & Cesium \\
\hline DQO & Data Quality Objective(s) \\
\hline DRO & Diesel-range organics \\
\hline FFACO & Federal Facility Agreement and Consent Order \\
\hline NAC & Nevada Administrative Code \\
\hline $\mathrm{Nb}$ & Niobium \\
\hline NTS & Nevada Test Site \\
\hline PAL & Preliminary action level(s) \\
\hline PCB & Polychlorinated biphenyl(s) \\
\hline $\mathrm{Pu}$ & Plutonium \\
\hline RCRA & Resource Conservation and Recovery Act \\
\hline R-MAD & Reactor Maintenance, Assembly, and Disassembly \\
\hline $\mathrm{Sr}$ & Strontium \\
\hline TPH & Total petroleum hydrocarbons \\
\hline $\mathrm{U}$ & Uranium \\
\hline
\end{tabular}




\section{Preface}

This document is an addendum to the Corrective Action Decision Document that has been prepared for Corrective Action Unit 254, Area 25 Reactor Maintenance, Assembly, and Disassembly (R-MAD) Decontamination Facility. The corrective action investigation was conducted in accordance with the Corrective Action Investigation Plan for Corrective Action Unit 254: Area 25 R-MAD Decontamination Facility, Nevada Test Site, Nye County, Nevada (DOE/NV, 1999) as developed under the Federal Facility Agreement and Consent Order (1996). Corrective Action Unit 254 consists of Corrective Action Site 25-23-06, Decontamination Facility.

The scope of this addendum consists of the following tasks:

- Develop corrective action alternatives.

- Perform detailed and comparative evaluations of the corrective action alternatives in relation to the corrective action objectives and screening criteria.

- Recommend and justify an alternate corrective action alternative for the Corrective Action Site.

The following corrective action alternatives were developed for consideration and are based on the review of existing data, future use, and current operations at the Nevada Test Site:

- Alternative 1 - No Further Action

- Alternative 2 - Unrestricted Release Decontamination and Verification Survey

- Alternative 3 - Unrestricted Release Decontamination and Verification Survey and Dismantling of Building 3126

The corrective action alternatives were evaluated against four general corrective action standards. Only Alternatives 2 and 3 were compared to the five remedy selection decision factors because Alternative 1 did not meet the unrestricted release criteria. Based on the results of these evaluations, the preferred corrective action alternative selected for Corrective Action Site 25-23-06, Decontamination Facility is Alternative 3, Unrestricted Release Decontamination and Verification Survey and Dismantling of Building 3126. 
The preferred corrective action alternative was evaluated on technical merit, focusing on performance, reliability, feasibility, and safety. The alternative was judged to meet all requirements for the technical components evaluated. The alternative for Corrective Action Site 25-23-06, Decontamination Facility meets all applicable state and federal regulations for closure of the site and reduces the potential for future exposure pathways.

During corrective action implementation, this alternative will present a potential threat to site workers who come in contact with the contaminated building materials and sediment during the removal process. Procedures will be developed, presented in the Corrective Action Plan, and implemented to ensure worker health and safety. 


\subsection{Introduction}

This Addendum to the Corrective Action Decision Document for Corrective Action Unit (CAU) 254, Area 25 Reactor-Maintenance, Assembly, and Disassembly (R-MAD) Decontamination Facility has been prepared to provide a rationale for recommendation of an alternative corrective action for CAU 254.

Corrective Action Unit 254 is located on the Nevada Test Site (NTS) in Nye County, Nevada. The NTS is approximately 65 miles northwest of Las Vegas, Nevada (Figure 1-1 and Figure 1-2).

Corrective Action Unit 254 is comprised of Corrective Action Site (CAS) 25-23-06, Decontamination Facility.

\subsection{Purpose}

The purpose of this Addendum is to provide a rationale for the recommendation of an alternative corrective action for CAU 254. The alternative corrective action is being recommended because a cost-effective technology is available to dismantle the building. The need for evaluation of corrective action alternatives is based on process knowledge and the results of the corrective action investigation conducted in January 2000, in accordance with the Corrective Action Investigation Plan (CAIP) for Corrective Action Unit 254: Area 25 R-MAD Decontamination Facility, Nevada Test Site, Nye County, Nevada (DOE/NV, 1999). The detailed results of the investigation are presented in the CAU 254 Corrective Action Decision Document (CADD) (DOE/NV, 2000).

\subsection{Scope}

The scope of this Addendum consists of the evaluation, identification, and recommendation of a revised preferred corrective action alternative to be implemented at the CAU 254 Site. To achieve this scope, the following actions have been taken:

- Reviewed corrective action objectives.

- Reviewed identified corrective action alternative screening criteria.

- Reviewed corrective action alternatives. 


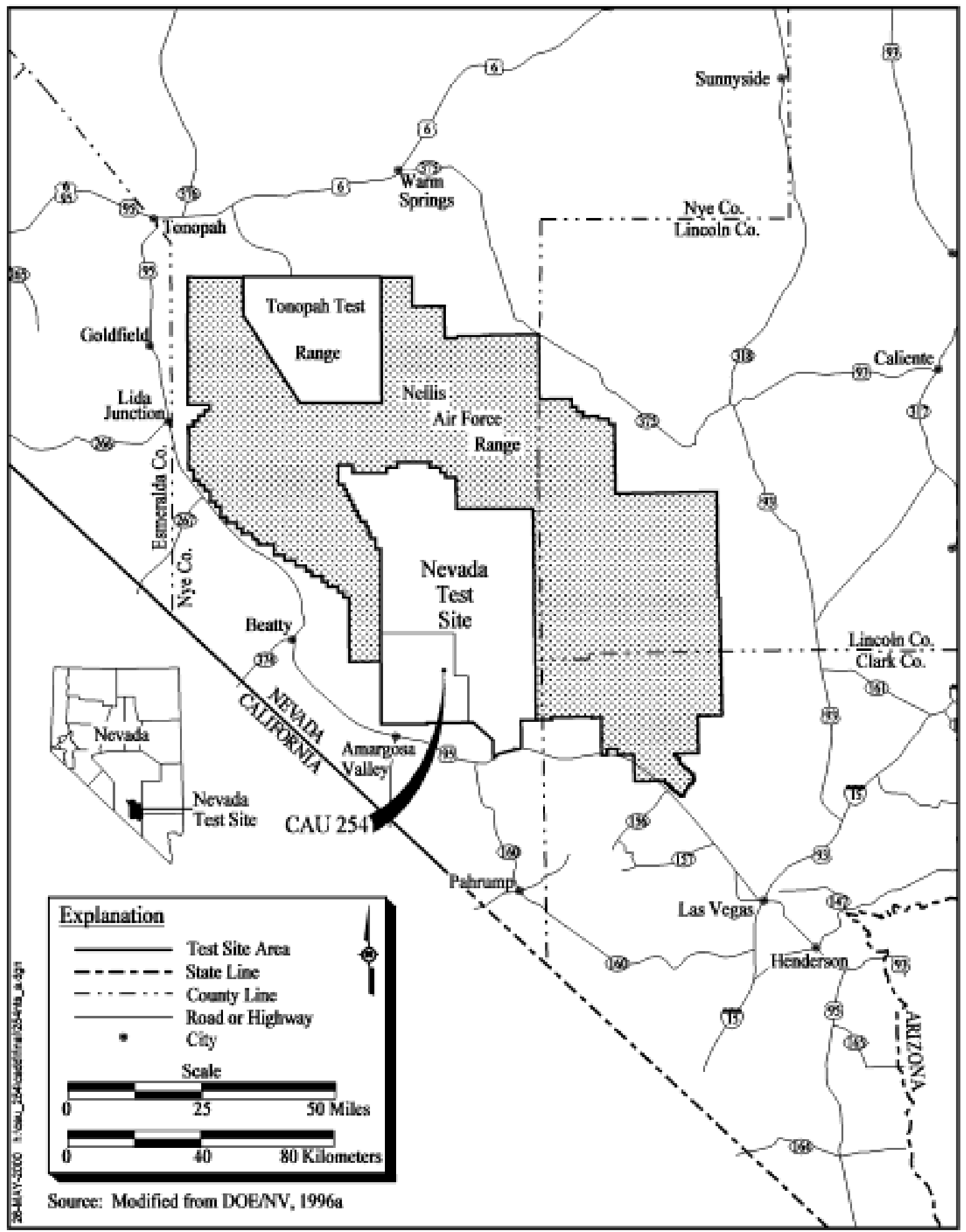

Figure 1-1

Nevada Test Site and CAU 254, Area 25 R-MAD Decontamination Facility, Location Map 


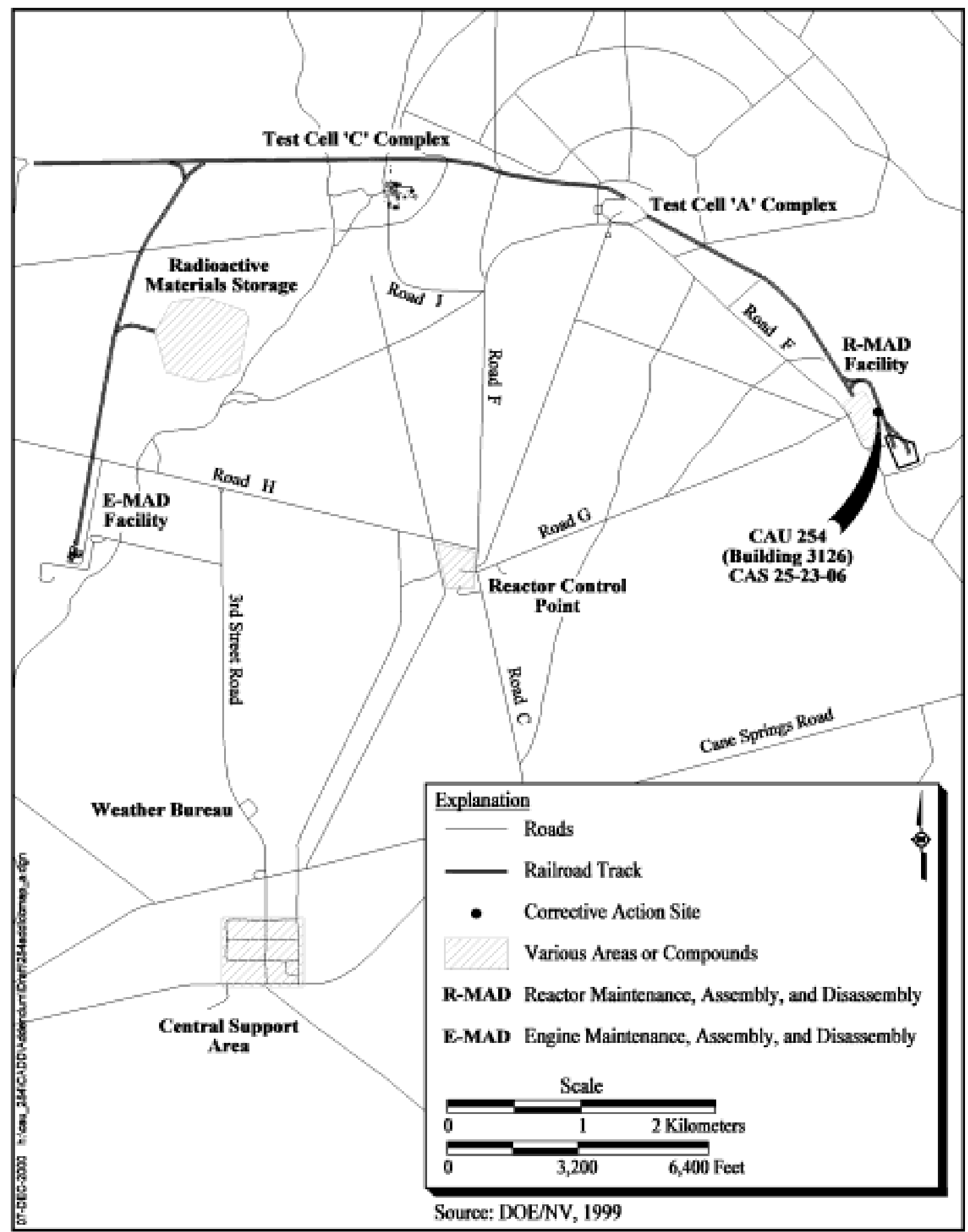

Figure 1-2

CAU 254, Area 25 R-MAD Location Map 
- Performed detailed evaluation of the corrective action alternatives in relation to corrective action objectives and screening criteria.

- Recommended and justified a preferred corrective action alternative for the CAU 254 Site.

\subsection{Addendum Contents}

This Addendum has been divided into the following sections:

- Section 1.0 - Introduction: summarizes the purpose, scope, and contents of this Addendum.

- Section 2.0 - Corrective Action Investigation Summary: summarizes the investigation activities, the results of the investigation, and the need for corrective action.

- Section 3.0 - Evaluation of Correction Action Alternatives: documents steps taken to determine a preferred corrective action alternative.

- Section 4.0 - Recommended Corrective Action Alternative: presents the preferred corrective action alternative and rationale for its selection based on the corrective action objectives and alternative screening criteria.

- Section 5.0 - Additional References: provides a list of additionally cited documents.

- Appendix A: Cost Estimates

All work was performed in accordance with the following documents:

- $\quad$ CAIP (DOE/NV, 1999)

- Industrial Sites Quality Assurance Project Plan (DOE/NV, 1996b)

- Federal Facility Agreement and Consent Order (FFACO, 1996)

- Project Management Plan (DOE/NV, 1994) 


\subsection{Corrective Action Investigation Summary}

The following sections describe and summarize the results of the corrective action investigation activities conducted at CAU 254. For detailed results of the CAU 254 corrective action investigation, refer to the CAU 254 CADD (DOE/NV, 2000).

\subsection{Corrective Action Investigation Activities}

The corrective action field investigation and sampling activities for CAU 254 were conducted by ITLV in January and February 2000, in accordance with the CAIP (DOE/NV, 1999). Preliminary work was conducted from mid to late 1999. A detailed discussion of the investigation activities is listed in Appendix A of the CAU 254 CADD (DOE/NV, 2000).

\subsection{Results}

Data was collected from the corrective action investigation activities conducted at CAU 254. Results from radiological surveys; on-site radiological analysis of swipe samples; and off-site laboratory analysis of soil, swipe, and building material samples indicate that radiological and chemical contaminants of concern (COCs) above preliminary action levels (PALs) are found in building materials and sediments at CAU 254. The analytical results supporting the investigation results are provided in Appendix A and Appendix D of the CAU 254 CADD (DOE/NV, 2000).

\subsection{Need for Corrective Action}

Analytes detected during the corrective action investigation were evaluated against PALs to determine COCs for the CAU 254 Site. Results from the radiological survey and the analysis of soil and building materials indicate that polychlorinated biphenyls (PCBs), Resource Conservation and Recovery Act (RCRA) metals, total petroleum hydrocarbons (TPH) as diesel-range organics (DRO), uranium (U)-234, U-235, petroleum (Pu)-239, Cs-137, niobium (Nb)-94, and strontium ( $\mathrm{Sr}$ )-90 exceeded the established PALs listed in the CAIP (DOE/NV, 1999). Based on the identification of COCs above PALs, potential corrective action alternatives were identified and evaluated in the CAU $254 \mathrm{CADD}$ (DOE/NV, 2000) to ensure worker, public, and environmental protection against potential exposure to COCs in accordance with the Nevada Administrative Code (NAC) 445A (NAC, 1998a). 


\subsection{Evaluation of Corrective Action Alternatives}

The purpose of this section is to present the corrective action objectives for the CAU 254 Site, describe the general standards and decision factors used to screen the corrective action alternatives, and develop and evaluate a set of corrective action alternatives that could be used to meet the corrective action objectives.

\subsection{Corrective Action Objectives}

Corrective action objectives are media-specific goals for protecting human health and the environment and constitute the basis for the development of corrective action alternatives. The proposed corrective action must be technically sound, provide a permanent solution for the site, and be cost-effective. In addition, the corrective action must be acceptable to the U.S. Department of Energy, Nevada Operations Office; Nevada Division of Environmental Protection; and the public. Based on the potential exposure pathways (see Section 3.1.2), the following corrective action objectives have been identified for CAU 254:

- Prevent or mitigate human exposure to soil and building material containing COCs at concentrations exceeding PALs, as defined in the CAIP (DOE/NV, 1999).

- Prevent human exposure to areas of surface contamination greater than the PALs for radionuclides present at the CAU 254 Site (DOE/NV, 1996c).

\subsubsection{Contaminants of Concern}

The contaminants of potential concern (COPCs) were determined in the Data Quality Objectives (DQO) process, as listed in the CAIP (DOE/NV, 1999). Analytical results obtained from the corrective action investigation were evaluated to determine if COPCs were detected above PALs. If the PALS are exceeded, those analytes become COCs and must be considered for corrective action. Based on the analytical results of the radiological surveys and building material samples, the following radionuclides have been identified as COCs for building materials: Sr-90, Cs-137, Nb-94, $\mathrm{U}-234, \mathrm{U}-235$, and Pu-239. Based on the analytical results of the soil samples collected from the storage yard at building 3126, the following radionuclides have been identified as COCs for soils: Sr-90, U-234, U-235, and Cs-137. 
Based on analytical results of soils and building material samples, the following chemical COCs have been identified for building materials: arsenic, chromium, lead, bis(2-ethylhexyl)phthalate, Aroclor-1260, Aroclor-1254, TPH diesel-range organics, and toluene. There were no chemical COCs identified for soil samples.

\subsubsection{Potential Exposure Pathways}

As identified in the CAIP, the future use for the CAU is assumed to be similar to current industrial use. As part of the CAIP (DOE/NV, 1999), a conceptual model for the CAU 254 Site was developed which identified potential exposure pathways including ingestion, inhalation, dermal contact, and direct exposure with contaminated soil and building material under an industrial-use scenario. Site personnel could potentially be exposed to the contaminated soil and building material during general facility maintenance or construction and maintenance of utilities, if corrective actions are not performed. Contaminant migration to the groundwater is not considered to be a significant exposure pathway because the low mobility of the COCs and depth to groundwater. Any migration of COCs is expected to be negligible.

\subsection{Screening Criteria}

The screening criteria used to evaluate and select the preferred corrective action alternatives consisted of a variety of general standards and decision factors described in Title 40, Code of Federal Regulations (CFR) Sections 260-271 (CFR, 1998), the U.S. Environmental Protection Agency's Guidance on Resource Conservation and Recovery Act Corrective Action Decision Documents (EPA, 1991), and the Final Resource Conservation and Recovery Act Corrective Action Plan (EPA, 1994). The general corrective action standards and the remedy selection decision factors are discussed in the CAU 254 CADD (DOE/NV, 2000).

\subsection{Development of Corrective Action Alternatives}

This section identifies and briefly describes the viable corrective action technologies and the corrective action alternatives considered for the affected media. Based on the review of existing data, future use, and current operations at the NTS, the following alternatives have been developed for consideration at CAU 254: 
- Alternative 1 - No Further Action

- Alternative 2 - Unrestricted Release Decontamination and Verification Survey

- Alternative 3- Unrestricted Release Decontamination and Verification Survey and Dismantling of Building 3126

Other alternatives, such as engineering or institutional controls, were considered; however, they were deemed to be inappropriate due to the limited extent of contamination and potential future uses of the site.

The two alternatives considered both specify the removal of all contamination exceeding PALs in soils and building materials at the site. An evaluation of NAC 445A.227 (2) (a-k) (NAC, 1998b) will not be conducted because impacts to groundwater are not expected. Therefore, groundwater monitoring is not proposed for this site and is not considered an element of the alternatives.

\subsubsection{Alternative 1 - No Further Action}

Under the No Further Action Alternative, no corrective action activities would be implemented. This alternative is used as a starting point to establish a baseline for comparison with the other corrective action alternatives. However, Alternative 1 does not meet the corrective action objectives for CAU 254 because it fails to meet the radiological unrestricted release criteria (DOE/NV, 1996c). For the purposes of this discussion, a comparison was made among Alternative 1, Alternative 2, and Alternative 3 to the general corrective action standards but not to the remedy selection decision factors. This comparison is shown in Table 3-1.

\subsubsection{Alternative 2 - Unrestricted Release Decontamination and Verification Survey}

Alternative 2 consists of the removal of accessible soil/sediment and building material from the CAU 254 Site with COC concentrations greater than the established PALs, in accordance with the CAIP (DOE/NV, 1999) and the corrective action objectives. After verification that the contamination has been removed, the remaining portions of the R-MAD Decontamination Facility will be released for unrestricted use.

Under this alternative, radiological or hazardous contaminated material removed from the CAU 254 Site would be disposed of at an approved waste management site. The facility will be field surveyed 
following removal of contaminated material and verification samples will be collected for laboratory analysis to verify unrestricted release criteria are achieved and all chemical COCs have been removed to less than PALs. This will ensure complete removal of contamination.

CAU 254 will be closed as described in this section and in accordance with NAC 445A

(NAC, 1998a).

\subsubsection{Alternative 3 - Unrestricted Release Decontamination, Verification Survey, and Dismantle of Building 3126}

Alternative 3 consists of the removal of accessible soil/sediment and all building material above ground level from the CAU 254 Site with COC concentrations greater than the established PALs, in accordance with the CAIP (DOE/NV, 1999) and the corrective action objectives. The building will be demolished and the portions of the building floor and concrete pads with radionuclide contamination greater than free release criteria or chemical contamination greater than PALs will be removed for disposal. The portions of the concrete pads and floor of the building that do not exceed free release criteria or PALs will remain. A use restriction will be placed on the remaining contaminated soil/sediment and remaining building foundation. After verification that the contamination has been removed, the remaining portions of the R-MAD Decontamination Facility floor and concrete pads will be released for unrestricted use.

Under this alternative, radiological or hazardous contaminated material removed from the CAU 254 Site would be disposed of at an approved waste management site. The facility will be field surveyed following removal of contaminated material and verification samples will be collected for laboratory analysis to verify unrestricted release criteria are achieved and all chemical COCs have been removed to less than PALs. This will ensure complete removal of contamination.

CAU 254 will be closed as described in this section and in accordance with NAC 445A (NAC, 1998a).

\subsection{Evaluation and Comparison of Alternatives}

An evaluation and comparison was made among Alternative 2 and Alternative 3 to the general corrective action standards described in the CAU 254 CADD (DOE/NV, 2000) and to the remedy 
selection decision factors. A comparison among the three alternatives for the remedy selection decision factors was not necessary because Alternative 1 does not meet the radiological unrestricted release criteria (DOE/NV, 1996c). A summary of the comparison among Alternative 1, Alternative 2, and Alternative 3, and the evaluation of Alternative 2 and Alternative 3 to the remedy selection decision factors are shown in Table 3-2. The advantages and disadvantages of each alternative were assessed to select a preferred alternative for the site. Cost summaries are provided in Appendix A of this Addendum. 
Table 3-1

Detailed Evaluation of the Corrective Action Alternatives for CAU 254, Area 25 R-MAD Decontamination Facility

(Page 1 of 4)

\begin{tabular}{|c|c|c|c|}
\hline Evaluation Criteria & $\begin{array}{c}\text { Alternative } 1 \\
\text { No Further Action }\end{array}$ & $\begin{array}{c}\text { Alternative } 2 \\
\text { Unrestricted Release } \\
\text { Decontamination and Verification } \\
\text { Survey }\end{array}$ & $\begin{array}{c}\text { Alternative } 3 \\
\text { Unrestricted Release } \\
\text { Decontamination, Verification Survey, } \\
\text { and Dismantle of Building } 3126\end{array}$ \\
\hline \multicolumn{4}{|c|}{ Closure Standards } \\
\hline $\begin{array}{l}\text { Protection of Human Health } \\
\text { and the Environment }\end{array}$ & 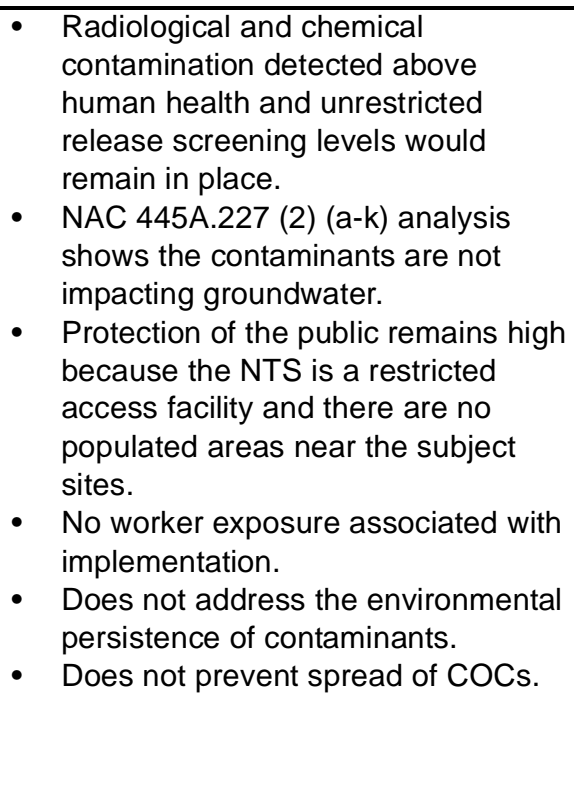 & $\begin{array}{l}\text { - Meets corrective action objectives by } \\
\text { removal of accessible contaminated } \\
\text { soil/sediment and building material in } \\
\text { excess of unrestricted release criteria } \\
\text { and PALs. } \\
\text { - Moderate exposure associated with } \\
\text { fugitive dust and/or contact with } \\
\text { impacted media during removal } \\
\text { activities. } \\
\text { Protection of the public remains high } \\
\text { because the NTS is a restricted } \\
\text { access facility and there are no } \\
\text { populated areas near the subject } \\
\text { sites. } \\
\text { Moving contaminated material to an } \\
\text { appropriate disposal facility } \\
\text { addresses the persistence of } \\
\text { contaminants. }\end{array}$ & $\begin{array}{l}\text { - Meets corrective action objectives by } \\
\text { removal of all contaminated soil and } \\
\text { building material in excess of } \\
\text { unrestricted release criteria and } \\
\text { PALs. } \\
\text { Moderate exposure associated with } \\
\text { fugitive dust and/or contact with } \\
\text { impacted media during removal } \\
\text { activities. } \\
\text { Protection to the public remains high } \\
\text { because the NTS is a restricted } \\
\text { access facility and there are no } \\
\text { populated areas near the subject } \\
\text { sites. } \\
\text { Moving contaminated material to an } \\
\text { appropriate disposal facility } \\
\text { addresses the persistence of } \\
\text { contaminants. } \\
\text { Demolition and disposal of remaining } \\
\text { building structure will limit future risk } \\
\text { from structural degradation. }\end{array}$ \\
\hline
\end{tabular}


Table 3-1

Detailed Evaluation of the Corrective Action Alternatives for CAU 254, Area 25 R-MAD Decontamination Facility

(Page 2 of 4)

\begin{tabular}{|c|c|c|c|}
\hline Evaluation Criteria & $\begin{array}{c}\text { Alternative } 1 \\
\text { No Further Action }\end{array}$ & $\begin{array}{c}\text { Alternative } 2 \\
\text { Unrestricted Release } \\
\text { Decontamination and Verification } \\
\text { Survey }\end{array}$ & $\begin{array}{c}\text { Alternative } 3 \\
\text { Unrestricted Release } \\
\text { Decontamination, Verification Survey, } \\
\text { and Dismantle of Building } 3126\end{array}$ \\
\hline $\begin{array}{l}\text { Compliance with Media } \\
\text { Cleanup Standards }\end{array}$ & $\begin{array}{l}\text { - Does not comply with media cleanup } \\
\text { standards because COCs remain at } \\
\text { levels above PALs and unrestricted } \\
\text { release criteria. } \\
\text { - NAC 445A.227 (2) (a-k) analysis } \\
\text { shows the contaminants are not } \\
\text { impacting groundwater. }\end{array}$ & $\begin{array}{l}\text { Limited compliance with media } \\
\text { cleanup standards because possible } \\
\text { soil/sediments and surface } \\
\text { contamination above unrestricted } \\
\text { release criteria may be present } \\
\text { beneath the remaining building } \\
\text { structure. } \\
\text { Removal locations will be field } \\
\text { screened to verify that radiation } \\
\text { activity is below unrestricted release } \\
\text { criteria. } \\
\text { Verification samples will be submitted } \\
\text { for laboratory analysis to confirm } \\
\text { removal of all COCs to less than } \\
\text { PALs. }\end{array}$ & $\begin{array}{l}\text { - Complies with media cleanup } \\
\text { standards because all sediments and } \\
\text { surface contamination above } \\
\text { unrestricted release criteria will be } \\
\text { removed and disposed of at an } \\
\text { appropriate facility. } \\
\text { - Removal locations will be field } \\
\text { screened to verify that radiation } \\
\text { activity is below unrestricted release } \\
\text { criteria. } \\
\text { Verification samples will be submitted } \\
\text { for laboratory analysis to confirm } \\
\text { removal of all COCs to less than } \\
\text { PALs. } \\
\text { Demolition of the structure above the } \\
\text { ground level will ensure that all } \\
\text { building material in excess of } \\
\text { unrestricted release criteria and } \\
\text { PALs will be removed. }\end{array}$ \\
\hline
\end{tabular}


Table 3-1

Detailed Evaluation of the Corrective Action Alternatives for CAU 254, Area 25 R-MAD Decontamination Facility

(Page 3 of 4)

\begin{tabular}{|c|c|c|c|}
\hline Evaluation Criteria & $\begin{array}{c}\text { Alternative } 1 \\
\text { No Further Action }\end{array}$ & $\begin{array}{c}\text { Alternative } 2 \\
\text { Unrestricted Release } \\
\text { Decontamination and Verification } \\
\text { Survey }\end{array}$ & $\begin{array}{c}\text { Alternative } 3 \\
\text { Unrestricted Release } \\
\text { Decontamination, Verification Survey, } \\
\text { and Dismantle of Building } 3126\end{array}$ \\
\hline $\begin{array}{l}\text { Control the Source(s) of } \\
\text { Release }\end{array}$ & $\begin{array}{l}\text { - There is no control of contaminant } \\
\text { release to humans or the } \\
\text { environment. }\end{array}$ & $\begin{array}{l}\text { At completion of the activities, } \\
\text { removed contaminated material will } \\
\text { be permanently removed from the } \\
\text { site and accessible surfaces will be } \\
\text { screened to verify that unrestricted } \\
\text { release criteria are achieved. } \\
\text { Verification samples will be submitted } \\
\text { for laboratory analysis to confirm } \\
\text { removal of all COCs to less than } \\
\text { PALs. }\end{array}$ & $\begin{array}{l}\text { - At completion of the activities, all } \\
\text { contaminated material will be } \\
\text { permanently removed from the site } \\
\text { and all surfaces will be screened to } \\
\text { verify that unrestricted release } \\
\text { criteria are achieved. } \\
\text { Verification samples will be submitted } \\
\text { for laboratory analysis to confirm } \\
\text { removal of all COCs to less than } \\
\text { PALs. } \\
\text { Demolition of the structure above the } \\
\text { ground level will ensure that all } \\
\text { building material in excess of } \\
\text { unrestricted release criteria and } \\
\text { PALs will be removed. }\end{array}$ \\
\hline $\begin{array}{l}\text { Comply with Applicable } \\
\text { Federal, State, and Local } \\
\text { Standards for Waste } \\
\text { Management }\end{array}$ & - No waste generated. & $\begin{array}{l}\text { All waste (primarily contaminated soil } \\
\text { and building material) will be handled } \\
\text { and disposed of in accordance with } \\
\text { applicable standards. }\end{array}$ & $\begin{array}{l}\text { - All waste (primarily contaminated soil } \\
\text { and building material) will be handled } \\
\text { and disposed of in accordance with } \\
\text { applicable standards. } \\
\text { Demolition of the structure above the } \\
\text { ground level will ensure that all } \\
\text { building material in excess of } \\
\text { unrestricted release criteria and } \\
\text { PALs will be removed. }\end{array}$ \\
\hline
\end{tabular}


Table 3-1

Detailed Evaluation of the Corrective Action Alternatives for CAU 254, Area 25 R-MAD Decontamination Facility

(Page 4 of 4 )

\begin{tabular}{|c|c|c|c|}
\hline Evaluation Criteria & $\begin{array}{l}\text { Alternative } 1 \\
\text { No Further Action }\end{array}$ & $\begin{array}{c}\text { Alternative } 2 \\
\text { Unrestricted Release } \\
\text { Decontamination and Verification } \\
\text { Survey }\end{array}$ & $\begin{array}{c}\text { Alternative } 3 \\
\text { Unrestricted Release } \\
\text { Decontamination, Verification Survey, } \\
\text { and Dismantle of Building } 3126\end{array}$ \\
\hline \multicolumn{4}{|c|}{ Remedy Selection Decision Factors } \\
\hline $\begin{array}{l}\text { Short-Term Reliability and } \\
\text { Effectiveness }\end{array}$ & - Not evaluated. & $\begin{array}{l}\text { Moderate risk to workers associated } \\
\text { with fugitive dusts, direct contact, and } \\
\text { heavy equipment. } \\
\text { - Public protected by remote location } \\
\text { and NTS site access controls. } \\
\text { - Limited environmental impacts are } \\
\text { possible due to implementation. } \\
\text { Implementation should not require an } \\
\text { extended period of time. }\end{array}$ & $\begin{array}{l}\text { - Moderate risk to workers associated } \\
\text { with fugitive dusts, direct contact, and } \\
\text { heavy equipment. } \\
\text { - Public protected by remote location } \\
\text { and NTS site access controls. } \\
\text { - Environmental impacts are not } \\
\text { anticipated due to implementation. } \\
\text { - Implementation should not require an } \\
\text { extended period of time. }\end{array}$ \\
\hline $\begin{array}{l}\text { Reduction of Toxicity, } \\
\text { Mobility, and/or Volume }\end{array}$ & - Not evaluated. & $\begin{array}{l}\text { Removal and clean closure of } \\
\text { accessible sediments and building } \\
\text { materials would effectively eliminate } \\
\text { associated toxicity, mobility, and } \\
\text { volume of materials at the site. }\end{array}$ & $\begin{array}{l}\text { Removal and clean closure of all } \\
\text { sediment and building materials } \\
\text { above the ground surface would } \\
\text { effectively eliminate associated } \\
\text { toxicity, mobility, and volume of } \\
\text { materials at the site. }\end{array}$ \\
\hline $\begin{array}{l}\text { Long-Term Reliability and } \\
\text { Effectiveness }\end{array}$ & - Not evaluated. & $\begin{array}{l}\text { Risk of exposure to accessible COCs } \\
\text { will be significantly reduced upon } \\
\text { completion of the corrective action. } \\
\text { Site would achieve unrestricted } \\
\text { release criteria for all accessible } \\
\text { areas. }\end{array}$ & $\begin{array}{l}\text { Risk of exposure to all COCs will be } \\
\text { significantly reduced upon } \\
\text { completion of the corrective action. } \\
\text { Site would achieve unrestricted } \\
\text { release criteria. }\end{array}$ \\
\hline Feasibility & - Not evaluated. & $\begin{array}{l}\text { Decontamination is easily } \\
\text { implemented for all accessible areas. }\end{array}$ & $\begin{array}{l}\text { Demolition and screening of building } \\
\text { materials prior to disposal is easily } \\
\text { implemented. }\end{array}$ \\
\hline Cost & $\$ 0$ & $\$ 769,275$ & $\$ 846,535$ \\
\hline
\end{tabular}


Table 3-2

\section{Evaluation and Comparison of the Corrective Action Alternatives} for CAU 254, Area 25 R-MAD Decontamination Facility

\begin{tabular}{|c|c|}
\hline Evaluation Criteria & Comparative Evaluation \\
\hline \multicolumn{2}{|r|}{ General Standards } \\
\hline $\begin{array}{l}\text { Protection of Human Health } \\
\text { and the Environment }\end{array}$ & - $\quad$ Alternatives 2 and 3 meet corrective action objectives. Moderate risks are associated with Alternatives 2 and 3. \\
\hline $\begin{array}{l}\text { Compliance with Media } \\
\text { Cleanup Standards }\end{array}$ & $\begin{array}{l}\text { - Alternative } 2 \text { removes accessible soil/sediment and building materials containing COCs at concentrations exceeding PALs } \\
\text { and eliminates exposure pathways at the site. Alternative } 3 \text { removes all soil/sediment and building materials above the } \\
\text { ground level containing COCs at concentrations exceeding PALs and eliminates exposure pathways at the site. }\end{array}$ \\
\hline $\begin{array}{l}\text { Control the Source(s) of } \\
\text { Release }\end{array}$ & - The sources to CAU 254 have been discontinued. \\
\hline $\begin{array}{l}\text { Comply with Applicable } \\
\text { Federal, State, and Local } \\
\text { Standards for Waste } \\
\text { Management }\end{array}$ & $\begin{array}{l}\text { - Alternatives } 2 \text { and } 3 \text { will generate minimal hazardous and low-level waste that will be handled in accordance with applicable } \\
\text { standards. Alternative } 3 \text { will generate larger volumes of sanitary waste that will be handled in accordance with applicable } \\
\text { standards. }\end{array}$ \\
\hline \multicolumn{2}{|r|}{ Remedy Selection Decision Factors } \\
\hline $\begin{array}{l}\text { Short-Term Reliability and } \\
\text { Effectiveness }\end{array}$ & - $\quad$ Moderate risks are associated with Alternative 2 and Alternative 3 during the dismantling and disposal of Building 3126. \\
\hline $\begin{array}{l}\text { Reduction of Toxicity, } \\
\text { Mobility, and/or Volume }\end{array}$ & - Alternatives 2 and 3 result in a reduction of all three characteristics at CAU 254. \\
\hline $\begin{array}{l}\text { Long-Term Reliability and } \\
\text { Effectiveness }\end{array}$ & $\begin{array}{l}\text { - Residual risk and administrative measures at CAU } 254 \text { are possible for Alternative } 2 \text { for inaccessible locations. Residual risk } \\
\text { will be nonexistent and administrative measures will not be required for Alternative } 3 \text {. }\end{array}$ \\
\hline Feasibility & - Alternatives 2 and 3 are feasible; however, Alternative 3 will be more resource intensive. \\
\hline Cost & $\begin{array}{l}\text { The estimated cost for Alternative } 2 \text { is } \$ 769,275 \text {. The estimated cost for Alternative } 3 \text { is } \$ 846,535 \text {. Revised cost estimate } \\
\text { pending from BN. }\end{array}$ \\
\hline
\end{tabular}




\subsection{Recommended Corrective Action Alternative}

Based on the results of the detailed analysis of the potential corrective action alternatives presented in this document, the preferred corrective action alternative selected for implementation at CAU 254 is Alternative 3. Alternative 3 was chosen for the following reasons:

- Risk to human health is minimal from the removal of surface contamination in excess of unrestricted release criteria and disposal at an appropriate facility. Appropriate As-Low-AsReasonably-Achievable (ALARA) principles will be utilized to minimize worker risk during removal activities.

- Provides a cost-effective method for achieving protection of human health and the environment and meeting unrestricted release requirements.

- All waste will be managed in accordance with federal, state, and local requirements.

- Long-term risks are significantly reduced by removing and disposing of contaminated soil and/or building material to an appropriate disposal facility and demolition of remaining building material.

- Easily implemented with standard construction equipment utilized for decontamination and removal of contaminated material, and demolition of remaining building structure.

The preferred corrective action alternative was evaluated on its technical merits, focusing on performance, reliability, feasibility, and safety. The alternative was judged to meet all requirements for the technical components evaluated. The alternative meets all applicable state and federal regulations for closure of CAU 254 and reduces the potential for future exposure pathways.

During corrective action implementation, this alternative may potentially present moderate to high industrial safety risks to site workers. Therefore, appropriate health and safety procedures should be developed and implemented.

Based on the evaluation in this CADD Addendum, closure of the CAU 254 Site by Alternative 3 is the preferred closure method. 


\subsection{References}

CFR, see Code of Federal Regulations.

Code of Federal Regulations. 1998. Title 40 CFR Parts 260 - 282, "RCRA Regulations."

DOE/NV, see U.S. Department of Energy, Nevada Operations Office.

EPA, see U.S. Environmental Protection Agency.

FFACO, see Federal Facility Agreement and Consent Order.

Federal Facility Agreement and Consent Order. 1996, as amended. Agreed to by the State of Nevada, the U.S. Department of Energy, and the U.S. Department of Defense.

NAC, see Nevada Administrative Code.

Nevada Administrative Code. 1998a. NAC 445A, "Water Controls." Carson City, NV.

Nevada Administrative Code. 1998b. NAC 445A.227, "Contamination of Soil: Order by director for corrective action; factors to be considered in determining whether corrective action is required. Carson City, NV.

U.S. Department of Energy, Nevada Operations Office. 1994. Project Management Plan, Rev. 0. Las Vegas, NV.

U.S. Department of Energy, Nevada Operations Office. 1996a. Final Environmental Impact Statement for the Nevada Test Site and Off-Site Locations in the State of Nevada, DOE/EIS 0243. Las Vegas, NV.

U.S. Department of Energy, Nevada Operations Office. 1996b. Industrial Sites Quality Assurance Project Plan, Nevada Test Site, Nevada, Rev. 1, DOE/NV--372. Las Vegas, NV.

U.S. Department of Energy, Nevada Operations Office. 1996c. NV/YMP Radiological Control Manual, Rev. 2, DOE/NV/11718--079, UC-702. Prepared by A.L. Gile of Bechtel Nevada. Las Vegas, NV.

U.S. Department of Energy, Nevada Operations Office. 1999. Corrective Action Investigation Plan for Corrective Action Unit 254: Area 25 R-MAD Decontamination Facility, Nevada Test Site, Rev. 0, DOE/NV--557. Las Vegas, NV. 
U.S. Department of Energy, Nevada Operations Office. 2000. Corrective Action Decision Document for Corrective Action Unit 254: Area 25 Reactor-Maintenance, Assembly, and Disassembly Decontamination Facility, Rev. 0, DOE/NV--619. Las Vegas, NV.

U.S. Environmental Protection Agency. 1991. Guidance on RCRA Corrective Action Decision Documents, EPA/540/G-91/011. Washington, DC: Office of Research and Development.

U.S. Environmental Protection Agency. 1994. Final RCRA Corrective Action Plan, EPA/520-R-94-004. Washington, DC: Office of Solid Waste and Emergency Response. 
Appendix A

Cost Estimates 
SUBJECT: Area 25 R-MAD Decontamination Facility, Nevada Test Site

ESTIMATOR: Don Jenkins. 295-0217

RFE \#:

$\longrightarrow$

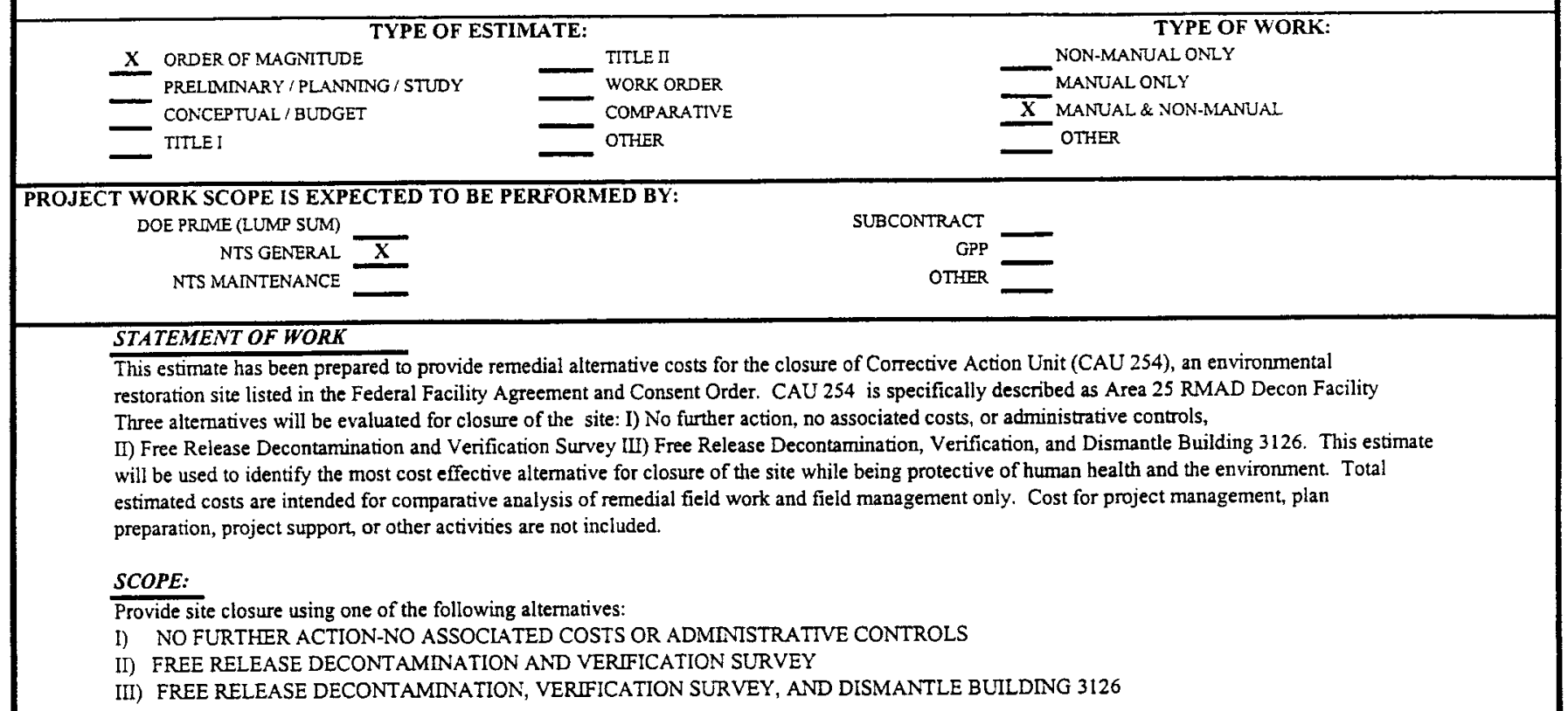

BASIS:

This estimate was priced using standard construction such as RS Means, Richardson's and the BN estimating data base

\section{ALTERNATUVE SPECIFIC BASIS OF ESTIMATE/ASSUMPTIONS}

Alternative لll: Free Release Decontamination and Verification Survey

* A bioassay program, health physics support and RCT support will be required for work to be performed in hot areas.

* Assume PPE requirements will include levels $C$ and $D$.

* All surface contamination greater than free release levels will be removed. Locations will be field screened after removal activities to verify radiation activity is below the free release criteria.

- Decontamination activities will include removal of contaminated wall board (containing asbestos), plywood, doors, insulation, and asbestos encapsulating piping in the decontamination bay and loft. Concrete within Building 3126 , and the east and west decontamination pads, will be shot blasted to remove contamination greater than free release levels.

* 100 cubic yards of soil adjacent to the decontamination pads will be removed and disposed as low level radioactive waste.

* The compressor, and 1,140-gal above ground storage tank outside Building 3126 will be removed.

Alternative U: Free Release Decontamination, Verification Survey, and Dismantle Building 3126

- A bioassay program, health physics support and RCT support will be required for work to be performed in hot areas.

- Assume PPE requirements will include levels $C$ and $D$.

* All surface contamination greater than free release levels will be removed. Locations will be field screened after removal

activities to verify radiation activity is below the free release criteria.

* Decontamination activities will include removal of contaminated wall board (containing asbestos), plywood, doors, insulation, and asbestos encapsulating piping in the decontamination bay and loft. Concrete within Building 3126, and the east and west decontamination pads, will be shot blasted to remove contamination greater than free release ievels.

- 100 cubic yards of soil adjacent to the decontamination pads will be removed and disposed as low level radioactive waste.

* The compressor and 1,140-gal above ground storage tank outside Building 3126 will be removed.

- Dismantic Building 3126. 
SUBJECT: Area 25 R-MAD Decontamination Facility, Nevada Test Site

ESTIMATOR: Don Jenkins, 295-0217 RFE \#:

Review / Concurrence:

ASSUMPTIONS:

- Work to be preformed by BN during normal work day (No provisions for overtime provided). Shifrs are based on 10 hours per day / 4-days per week.

* Efficiencies will be realized as work will be performed on similar activities completed in parallel or concurrently

* This estimate does not include costs for preparation of Corrective Action Plan ( CAP) or a Closure Report

* Soil borrow area is within one ( 1 ) mile of site.

\section{ESCALATION:}

No escalation factors have been applied. All costs are in FY01 dollars.

\section{CONTINGENCY:}

Contingency costs are not included in this estimate as directed by DOE / NV

RATES:

FY01 rates (Rev 0) effective 10/1/00 were applied using the BN FY00 cost model.

\section{COST ALTERNATIVES SUMMARY:}

Alternative I: No Action To Be Taken
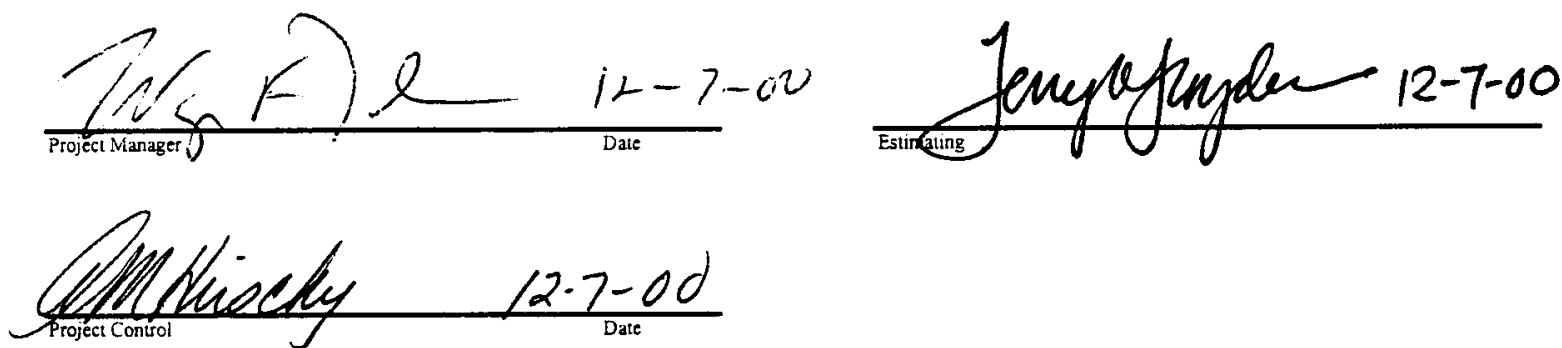


\section{Distribution}

* Provide copy in distribution of Rev. 0 and subsequent revisions, if applicable.

Copies of the NDEP-approved document will be distributed to others.

\section{$\underline{\text { Copies }}$}

Paul J. Liebendorfer

2 (Controlled)*

State of Nevada

Bureau of Federal Facilities

Division of Environmental Protection

333 W. Nye Lane, Room 138

Carson City, NV 89706-0851

Michael McKinnon

1 (Controlled)*

State of Nevada

Bureau of Federal Facilities

Division of Environmental Protection

555 E. Washington, Suite 4300

Las Vegas, NV 89101

Sabrina Lawrence

1 (Controlled)*

Environmental Restoration Division

DOE/Nevada Operations Office

P.O. Box 98518, M/S 505

Las Vegas, NV 89193-8518

Janet Appenzeller-Wing

1 (Uncontrolled)*

Environmental Restoration Division

DOE/Nevada Operations Office

P.O. Box 98518, M/S 505

Las Vegas, NV 89193-8518

Sabine Curtis

1 (Uncontrolled)*

Environmental Restoration Division

DOE/Nevada Operations Office

P.O. Box 98518, M/S 505

Las Vegas, NV 89193-8518 
Dennis Gustafson

Bechtel Nevada

P.O. Box 98521, M/S NTS306

Las Vegas, NV 89193-8521

Wayne Johnson

Bechtel Nevada

P.O. Box 98521, M/S NTS306

Las Vegas, NV 89193-8521

Linda Linden

ITLV

P.O. Box 93838

Las Vegas, NV 89193

Jeff Johnson

ITLV

P.O. Box 93838

Las Vegas, NV 89193

Jill Dale

ITLV

P.O. Box 93838

Las Vegas, NV 89193

IT Corporation Central Files

ITLV

P.O. Box 93838

Las Vegas, NV 89193

Technical Information Resource Center

DOE/Nevada Operations Office

P.O. Box 98518, M/S 505

Las Vegas, NV 89193-8518

U.S. Department of Energy

Office of Scientific and Technical Information

P.O. Box 62

Oak Ridge, TN 37831
1 (Uncontrolled)*

1 (Uncontrolled)*

1 (Uncontrolled)*

1 (Uncontrolled)*

1 (Uncontrolled)*

1 (Uncontrolled)*

1 (Uncontrolled)

1 (Uncontrolled, electronic copy) 
Manager, Southern Nevada FFACO

Public Reading Facility

P.O. Box 98521, M/S NLV040

Las Vegas, NV 89193

Manager, Northern Nevada FFACO

Public Reading Facility

c/o Nevada State Library \& Archives

Federal Publications

100 North Stewart Street

Carson City, NV 89701-4285

FFACO Support Group Coordinator

IT Corporation

P.O. Box 93838

Las Vegas, NV 89193
1 (Controlled)

1 (Uncontrolled)

1 (Uncontrolled)
1 (Controlled) 